Q L [From the Transaotrons of the Royal Society of Canada, Vol. IV. Sec. IV. 1886] 362

UC-NRLF

C ᄅ 739255

ON SOME

\title{
MARINE INVERTEBRATA
}

\begin{abstract}
DREDGED OR OTHERWISE COLLECTED BY DR. G. M. DAWSON, IN 1885, ON 'THE COAST OF BRITISH COLUMBIA; WITH A SUPPLENENTARY LIST OF A FEW LAND AND FRESH WATER SHELLS, FISHES, BIRDS, ETC., FROM THE SAME REGION
\end{abstract}

BY

J. F. WHITEAVES, F.G.S.

MONTREAL

DAWSON BROTHERS, PUBLISHERS 

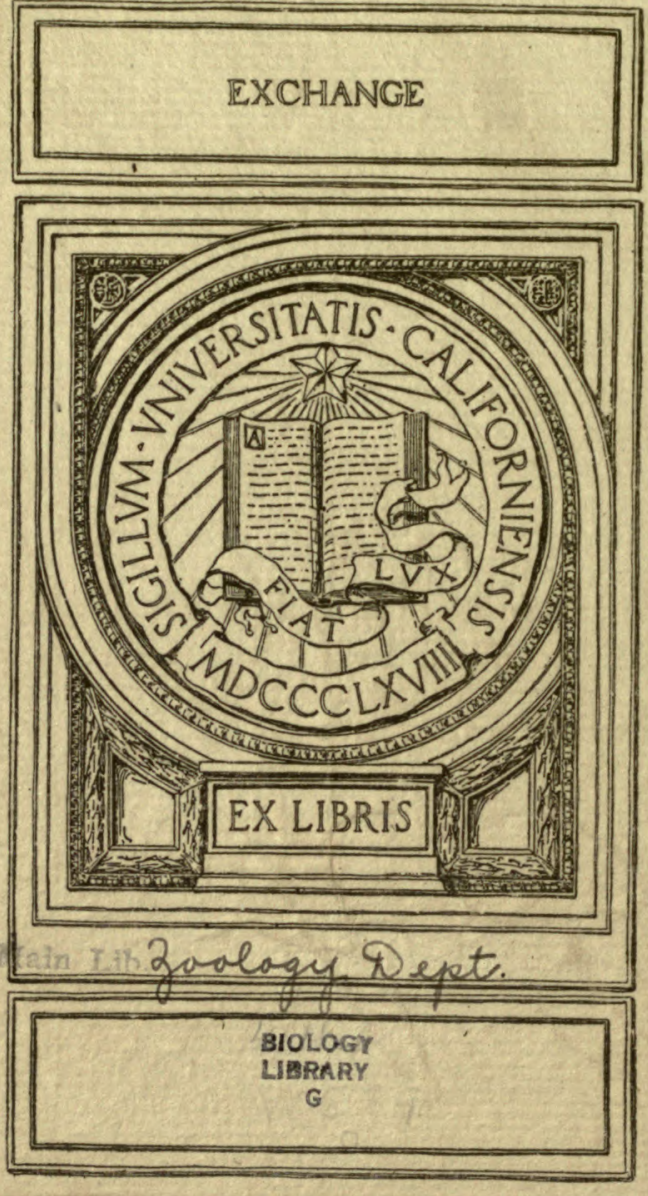


IX.-On some Marine Invertebrata dredged or otherwise collected by Dr. G. M. Dawson, in 1885, in the northern part of the Strait of Georgia, in Discovery Passage, Johnstone Strait, and Queen Charlotte and Quatsino Sounds, British Columbia; with a Supplementary List of a few land and fresh water shells, fishes, birds, ele., from the same region. By J. F. Whiteaves.

(Road Mlay 27, 18s6.)

As stated in his preliminary report, ${ }^{1}$ Dr. Dawson's geological explorations of certain parts of the coast of British Columbia, in the summer of 1885 , in which he was assisted by Mr. D. B. Dowling, were prosecuted by means of a schooner. In the intervals of the more purely geological work, this mode of locomotion afforded many opportunities, which were ntilized to their fullest extent, for collecting marine invertebrata, on the shore, by the towing net or by the dredge. The title of the present paper sufficiently indicates the area examined, at many points within which collections were made at low tide. The material collected by the towing net, being to a large extent microscopical in its character, has not yet been examined. The dredge was used successfully at depths of of from seven to fifty fathoms, at the following localities:-

Stamons. Strait of Geoligia.

No. 1.-Ballinac ('hannel, opposite Lasqueti Island, in forty fatlıoms.

2.-False Bay, Lasqueti Island, in ten to twenty fathomo, sand and gravel.

3.- Off the mouth of Qualicum Rivor, Vancouver Island, in forty fathoms, sand and gravel.

4.-Off the north end of Toxada Island, in fifty fathoms, sandy mud,

5.-Between Hernando and Cortez Islands, in eight to twenty fathoms, sand.

6.-Between Mary and Cortez Islands, in fifteen to twenty fatloms, sand.

\section{Discovery P'assage.}

7.-Duncan Jay, Vancouvor Island, in ten to twenty fatlioms, sand and gravel.

8.-Elk Bay, Vancouver Island, in twenty to twenty-five fathoms, sand and gravel.

\section{JohxstoNe Strait.}

9.-Blinkinsop Bay, on the mainland of British Columbia, in ten fathoms, sand and mud. 10.-Forward Bay, Cracroft Island, iu fifteen to twenty-frve fathoms.

\section{Qunin Charlotie Souxd.}

(Including Blackfislı and Fifo Sounds and Broughton Strait.)

11.-Farowell Iarbour, between Swanson, Lewis and Berry Islands, in nine fathoms, gravel.

12.-Fresh Water Bay, Swanson Island, Blackfish Sound, in ton fathoms, gravel and coarse sand.

Suminary Report of the Operations of the Geological and Natural Hiatory Survey of Cauada to Decenber 3Ist, 1885. Ottawa, 1886, pp. 4, 8. 


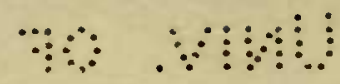

$\therefore$

STATIONS.

\author{
Quenn Charlotre Sound. (Continued.)
}

No. 13. - Cullen Harbour, Brougliton Island, Fifo Sounl, in four to eight fatloms, sand and mud.

14.-Alert Bay, on the west coast of Cormorant lsland, and nearly opposite the mouth of the Nimpkish liver, Vancouver Island, in Broughton Strait, in ten fathoms, sand and mud.

15.-Between Alert Bay and the mouth of the Nimpkish River, Vancouver Island, in ten to twenty fathoms, gravel.

16.-Noar Suquash, off Pulteney Point, Malcolm Island, Broughton Strait, in twenty-fivo fathoms, sand, gravel and dead sliells.

17.-Off False Head, Vancouver Island, in thirty fathoms, sand, gravel and dead shells.

18.-Off Blunden Harbour, mainland of British Columbia, in six to ten fathoms, sand.

Quatsino SoUnd, NORTH-WEST COAST OF VAxCOUver ISLAND.

19.-Quatsino Sound, off Entrance Island, in from thirty to fifty fathoms, mud and sand.

20.- Forward Inlet, Quatsino Sound, in ten to iwenty fathoms, inud.

Owing to the systematic way in which the collections were made, the series of marine invertebrata llow reported upon is by far the most extensire and important that has yet been made by any of the exploring parties of the Survey. The crustacea, with the exception of the minute and for the most part larral forms collected in the towing net, have been kindly examined by Prof. S. J. Smith, of Yale College, who will report on them separately. The sponges, hydroids (with one exception), polyzoa, and worms, have not yet been studied. Including the foraminifera, the number of species that have been identified so far is approximately as follows :-

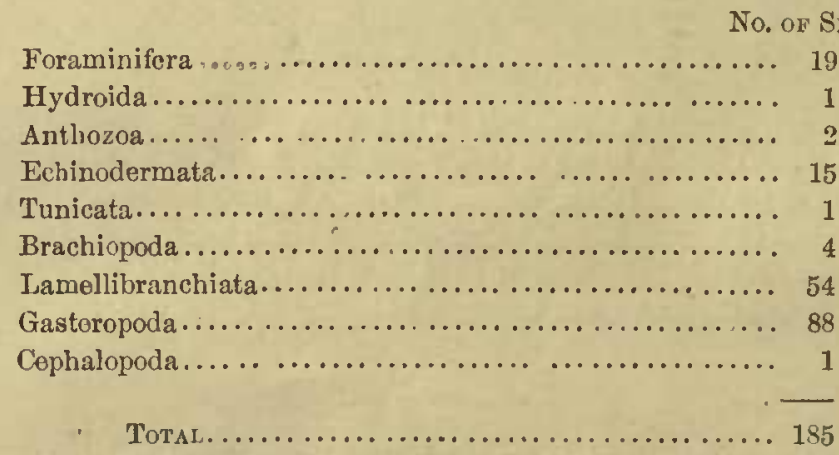

At station No. 7, the sand which came up in the dredge, when washed and examined under the microscope, was found to be unusually rich in diatomacere. Among these, connected frustules of Himantidium, Tabellaria and Grammatophora marina are frequent, associated with separate frustules of Arachnoidiscus Ehrenbergii (rare), Anphitetras antediluviana, and of species belonging to the genera Amphora, Campylodiscus, Coscinodiscus, Fragilaria, Gyrosigma, Licmophora, Navicula, Podosphcenia, Surirella and Triceratium.

Samples of the sand, mnd, etc., dredged from the bottom at ten of these stations were saved to be examined for foraminifera. The species from the Vancouver district do not appear to have previously been strdied by any naturalist, and the present list of the foraminifera of that region, though making no pretence to completeness, is believed to be the first that has yet been published. The largest and most conspicuous form is the Rhabdammina abyssorum of M. Sars, which was taken abundantly at three of the stations. 
It had been dredged by the writer before, in 1873, at a depth of 200 fathoms in the Gulf of St. Lawrence. Other remarkible forms are donble examples of Discorbina Iarisiensis, which are far from uncommon in Dr. Dawson's dredgings; large varieties of Cristcllaria cultrala, and a Frondicnlaria which, although conmon as a fossil in the Chalk of Europe and England, was previonsly unknown as a living species.

Among the echinodermata, the most interesting species collected is the Astrogonium granulare, which is new to the famn of the Pacific.

Of the lamellibranchiate bivalves, two, viz., Pecten Alaskensis and Yoldia thraciaformis, are arctic or subarctic shells which had not previously been taken so far to the sonth as the Vancouver region, while, on the other hand, Limatula subauriculata and Lede acuta are species which have not hitherto been recorded as occurring so far to the north, on the west coast of North America.

The number of species of gasteropoda collected is unusually large, and among these, Leptochiton cancellatus, Bela violacea, Cancellaria circumcincta, Admete viridula, and Sipho Verkrnzeni are northern forms new to the Vancouver district; while Solariella peramabilis and Barleeia subtenuis are Californian shells now for the first time placed upon record as living within it. Astarte undatu and Eulima incurva (=distorta auct.) if correctly identified, seem to be new to the fanna of the west coast of North America; Margarila cidaris, of which a fine series was obtained, was previously known only from a single specimen; and Cadulus aberrans and Leptochiton punctatus are here described for the first time.

It would appear that the outer and exposed western coast of Vancouver Islandis tenanted by a somewhat different assemblage of marine invertebrata from that which lives in its eastern, south-eastern and more land-locked waters. So far, Tellina Bodegensis, Cadulus aberrans, Pachypoma gibberosum, Chlorostoma finebrale and Olivella biplicata have been found by the Survey collectors on the west and north coast of the Island only, while Acntca instabilis, Cryptobranchia concentrica, IIaliotis Kamtsehatkana and Phorcus pulligo, though not exclusively confined to the outer coast, appear to be rare in its eastern and southeastern waters. The exact geographical distribution of the different species around the coast of Vanconver Island, however, has yet to be ascertained, and the preceding remarks have only been written with the riew of directing attention to the subject.

For critical and valuable suggestions in regard to some of the mollusca collected, and for the identification of eight species of gasteropoda, the writer is indebted to Mr. W. H. Dall of the United States National Museum at Washington.

The following is a list of the species that have been identified so far.

\section{Foraminifera.}

Miniolina seminulum, $L$. Strait of Georgia at station No. 2, Discorery Passage at station No. $\boldsymbol{T}$, and Queen Charlotte Sonnd at station No. 17, - one specimen at each.

Miliolina Ferussaci, d'Orbigny. With the preceding at station No. 17, one specimen.

Rifabdamina abyssorum, $\boldsymbol{M}$. Sars. Strait of Georgia at stations Nos. 4 and 5 , Queen Charlotte Sonnd at station No. 17, and Quatsino Sound at station No. 20,-abundant at each, 
Haplophragmium Canariense, d'Orbigny. Strait of Georgia at station No. 3, Discovery Passage at station No. 7, Queen Charlotte Sound at station No. 17, and Quatsino Sound at station No. 20,-not rare.

Troohammina squamata, Jones and Parker. Strait of Georgia at station No. 2, and Quatsino Sound at station No. 19,-not common.

Bulimina PYRULA, d'Orbigny. Johmstone Strait at station No. 9, five specimens.

Lagena sulcata, Walker and Jacob. Discovery Passage at station No. 7, a few specimens.

Nodosaria (Dentalina) pauperata, d'Orbigny. Strait of Georgia at stations Nos. 2 and 4, but in very small numbers.

Frondioularia canaliculata, Reuss.

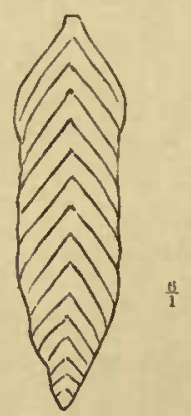

Fig. 1.-Frondicularia canaliculata, Reuss. Drawn from a living specimen dredged in the Strait of Georgia, and enlarged six diameters.

Verstein Bohm. Kreid, 1845, Pt. I. p. 31. Pl. VIII. Figs. 20, 21.

Strait of Georgia, at station No. 3, one perfect living specimen and a fragment of another, and at station No. 4, eight perfect and living specimens. This species, for the identification of which the writer is indebted to Mr. H. B. Brady, has long been known as a fossil of the Chalk Formation of Bohemia and England, but the specimens dredged by Dr. Dawson are the first that have been discorered in a living state.

Cristellaria culdrata, Montfort. Strait of Georgia at station No. 4, four specimens of a large variety in which the sutures are prominently overlaid by raised lines of shelly deposit.

Cristellakia CUltrata, var. With the terminal end straightened and the shape like that of $C$. reniformis and $C$. compressa, but the sutures are strongly arched. A single specimen from the same station as the preceding.

Polymorphina LadteA, Walker and Jacob. Discovery Passage at station No. 7, one specimen.

Porymorphina compressa, d'Orbigny. Strait of Georgia at station No. 4, Queen Charlotte Sound at stations Nos. 13 and 17, and Quatsino Sound at station No. 20,- not uncommon. Some of the specimens have as mally as twelre segments, and the sutures are not excavated. 
Discorbina Parisiensis, d'Orbigny. Discovery Passage at station No. 7, and Queen Charlotte Sound at stations Nos. 14 and 17,-not uncommon. Double specimens, in which the bases of two shells have grown together, or specimens which have been double, but which have been broken apart by some cause unknown, are more frequent than normal and single examples. In the ninth volume of the Zoology of the "Challenger" Expedition (p. 649) Mr. Brady says "it is probable that the phenomenon is to be accounted for in the same way in all cases, that it is brought about by the extension of a lobe of sarcode from the mouth of the parent test, the subsequent division of the nucleus, and the continued growth of the new individual without separation from the parent, a very similar process to that minutely watched by Gruber in a species of Euglypha."

Truncatalina lobatula, Walker and Jacob. Abundant, living and attached to shells, stones, etc., at most of the stations at which the dredge was used. Dead and detached specimens are frequent also in sand, etc., from stations Nos. 2, 7 and 17.

Pulvinulina Karsteni, Reuss. Discovery Passage at station No. 7, four specimens, and Johnstone Strait at station No. 9, one specimen.

Rotalia BeccariI, $\dot{L}$. Discovery Passage at station No. 7, Queen Charlotte Sound at station No. 14 and Quatsino Sound at station No. 20,- a few examples at each.

Nonionina SCAPHA, Fichtel and Moll. Johnstone Strait at station No. 9, and Queen Charlotte Sound at station No. 17,-apparently not very common.

Polystomella crispa, L. Queen Charlotte Sound at stations Nos. 14 and 17, and Quatsino Sound at station No. 9,-not uncommon.

Polystomelia striatopunctata, Fichtel and Moll. Johnstone Strait at station No. 9, nine specimens. Two specimens were also noted in sand dredged at a depth of two fathoms in Comox Harbour, Vancouver Island.

\section{HydROZOA.}

Allopora venUsta, Verrill. Queen Charlotte Sound at station No. 15, several specimens.

\section{ANTHOZOA.}

Paracyathus caltha, Verrill. Strait of Georgia at station No. 5, one specimen, and station No. 6 , four specimens.

Balanophyluia Elegans, Verrill. Strait of Georgia at station No. 5, one specimen, and station No. 6, two specimens. Discovery passage at station No. 7, four specimens.

\section{OPHIUROIDEA.}

OpHioglypha LutKeni, Lyman. Discovery Passage at station No. 7, a few specimens, and Queen Charlotte Sound at station No. 17, abundant. 


\section{Asteroidea.}

Asterias ochracea, Brandt. Low water, Malaspina Inlet, one small specimell.

Asterias confreta, Stimpson. Low water, Malapina Inlet, five fine specimens. Discovery Passage, at low water, one specimen.

Asterias Troscheli, Stimpson. Several specimens of an Asterias with five long slender rays and a very small disk, which are probably referable to this species, were collected by Dr. Dawson at low water at the northern end of the Strait of Georgia, at the entrance to Malaspina Inlet, at Redonda Island (to the north-east of Cortez Island) and in Discovery Passage. The smaller specimens from these localities agree very well with Stimpson's description of $A$. Troscheli; but the larger ones, which attain to a maximum diameter of rather more than a foot, and which are not very well preserved, do not shew very clearly the peculiar pentagon formed by clusters of spines in the centre of the upper surface of the disk, nor the marked disparity in size between the larger and smaller dorsal spines, that are said to be characteristic of the species. These larger specimens are precisely similar to a starfish collected by Mr. James Richardson in 1874, at low water, near Victoria, Vancouver Island, which was doubtfully and perhaps incorrectly referred to the A. epichlora of Brandt in the "Canadian Naturalist" of December, 1878, but both they and it are quite different to the specimens from the Queen Charlotte Islands which were called $A$. epichlora, but with a query, by the writer, on Prof. Verrill's authority, in an appendix to Dr. Dawson's report on those islands. ${ }^{1}$ Since that appendix was written, however, two very typical and well preserved examples of A. Troscheli have been detected among Dr. Dawson's collections from the Queen Charlotte Islands.

Asterias HEXaCTIS, Stimpson. Taken rather sparingly, living, at low tide in Seymour Narrows, Discovery Passage, Johnstone Strait and Queen Charlotte Sound. A few badly preserved and small specimens of a six-rayed star-fish, which is also probably $A$. hexactis, were dredged at station No. 14 .

Pycnopodia helianthoidea, Brandl. (Sp.) Hernando Island, Strait of Georgia, at low water, one specimen.

Solaster Stimpson, Verrill. Low water at Port Neville, on the mainland of British Columbia and on the north side of Johnstone Strait,--several. Twelve specimens of a Solaster, which seems to be only a variety of this species, were dredged in Queen Charlotte Sound at station No. 14. These differ from the type of S. Stimpsoni principally in the unusually large size of the disc and in the shortness of the rays, which latter are uniformly ten in number. The spines at the angles near the mouth, also, are apparently more numerous.

Solaster Dawsoni, Verrill. Beach at Powell Island, Strait of Georgia; one adult example. Entrance to Malaspina Inlet, at low water; one small specimen. Low water at Johnstone Strait and in the Goletas Channel ; abundant.

\footnotetext{
${ }^{1}$ Report of Progress of the Geological Survey of Canada for 1878-79, p. 192 B.
} 
Cribrella lastuscula, Stimpson. Low water at the entrance to Malaspina Inlet, in the Goletas Channel, and on the coast between Nahwitti village and Quatsino Sound, - several from each of these localities.

Dermaster imbricatus, Perrier. (=Asteropsis imbricata, Grube.) Beach at Hernando Island, two large specimens; low water at the entrance to Malaspina Inlet, one specimen; and Johnstone Strait, one specimen.

MEDiaster equalis, Stimpson. Low water at the north end of Malcolm Island, Queen Charlotte Sound, one fine specimen.

Astrogonium granulare, $O$. F. Muller. One beautiful living example of this rare species, which is now for the first time recorded as occurring in the North Pacific, was dredged in forty fathoms in the Strait of Georgia, off the mouth of the Qualicum River. It is almost precisely similar to a specimen of the same species taken some years ago off Halifax, Nova Scotia, and now in the Redpath Museum in Montreal. For the loan of the latter, for comparison, the writer is indebted to Sir William Dawson.

\section{ECHINOIDEA.}

Dendraster Excentricus, Valenciennes. (Sp.) Beach at Mary Island, Strait of Georgia, several dead and bleached specimens denuded of their spines. Low water at Savary Island, in the same strait, alive and numerous.

Loxechinus purpuratus, Stimpson. (Sp.) Common almost everywhere along the coast.

Strongylocentrotus Drobachiensis, Mull. With the preceding, and equally common.

\section{HoLOTHUROIDEA.}

Pentacta frondosa, Gunner. Two specimens of a very large Holothurian which appear to belong to this species, though they have not been examined microscopically, were dredged in Queen Charlotte Sound; one at station No. 11 and one at station No. 12.

A number of small Holothurians, which have yet to be studied, were dredged in Queen Charlotte Sound, at station No. 14.

\section{Tunicata.}

Cynthia (Halocynthia) Pyriformis, Rathke. Queen Charlotte Sound at station No. 18, two living specimens.

\section{BRACHIOPODA.}

Rhynchonella psittacea, $L$. Discovery Passage at station No. 7, one fresh ventral valve. Low tide, Johnstone Strait, a few small but living specimens. 
Terebratulina unguicula, Carpenter. Strait of Georgia, near Comox, in forty fathoms; one small living specimen. Discovery Passage at station No. 7, a large ventral valve. Low tide, Johnstone Strait, one small living specimen; and Johnstone Strait at station No. 10, two small living specimens.

The Terebratula unguicula of the late Dr. P. P. Carpenter was regarded as merely a local variety of the Enropean T. caput-serpentis by the late Dr. Thomas Davidson. A series of adult and perfect examples of T. unguicula, dredged by Mr. James Richardson in 1876 in the Strait of Georgia, was sent by the writer to Dr. Davidson, for examination, in the fall of 1884. In a letter dated Norember 29, 1884, Dr. Daridson writes:- "The specimens mamed Terebratulina unguicula are only a variety of T.caputserpentis. I will describe it in my monograph" (one on recent brachiopoda, then in course of preparation) "as Terebratulina raput-serpentis, var. unguicula, Carpenter. I compared all your Vancouver examples very mimutely with a number of European specimens of Linue's species, and feel confident that $T$. unguicula is not a distinct species."

Laqueus Californicus. Koch. Discovery Passage at station No. 7 , one dead but perfect shell and a large dorsal valve. Johnstone Strait at station No. 10, five liring adult specimens and sereral young. Race Passage, Johnstone Strait, two small but living specimens.

Terebratelda transversa, Sowerby. (=T. caurina, Gould.) Low tide, Strait of Georgia, many small but living and strongly ribbed specimens. Entrance to Malaspina Inlet, at low water, one living specimen. Discorery Passage at station No. 7, three small living specimens and one dead shell. Johnstone Strait at station No. 10, two adult living shells and one small one. Queen Charlotte Sonnd at station No. 12, one small living shell, and at station No. 18, five-small, living specimens.

At these localities, some of the specimens have strong, radiating ribs, while others are almost entirely smooth, but there are intermediate gradations between the ribbed and the smooth forms, which latter is the one represented by Sowerby in the "Thesaurus Conchyliormm," as the type of T. transversa.

\section{LAMELLIBRANCHIATA.}

$\checkmark$ Piacunanomia macroscinsma, Deshayes. Entrance to Malaspina Inlet, at low water; three small, living specimens attached to Ostrea lurida. Strait of Georgia at station No. 2, two rather small, living specimens. Quatsino Sound, Vancouver Island, one large and two small living shells.

Ostrea luRida, Carpenter. Entrance to Malaspina Inlet, at low tide, two living specimens. A number of good specimens of this species, which were said to have been taken near Comox, were purchased in Victoria, Vancouver Island. Bradley Lagoon, Blunden Harbour, Queen Charlotte Sound, on the mainland side, abundant. This last is the most northerly locality yet recorded for oysters on the coast of British Columbia. 
Hinnites Gicasteds, Gray. Eutrance to Malaspina Inlet, associated with the two preceding species, one rather small and dead specimen. Low water at Fort Rupert, on the north-east const of Vancouver Island, one adult living shell, and a similar one from the entrance to Quatsino Sound, also at low water.

Pecten Aidsiensis, Dall. Quatsino Sound at station No. 20, one small but living specimen. This species, which has hitherto been recorded as occurring only at "North Iarbor, Unga Island," and "Port Etches, Chugach Gulf," is new to the Vancouver region.

Pecten hastatus, Soverby. (=P. hericeus, Gld.) Strait of Georgia at station No. 6, one living, adult shell, with the exterior of both valves nearly covered by an eucrusting sponge. Goletas Channel, one small but living shell. Quatsino Sound at station No. 19, five adult, living and brightly coloured specimens of the typical form of the species, in which the principal ribs are few, distant, and ornamented with erect raulted scales.

Pecten hastatus, var. Hindsi. Carpenter. Strait of Georgia at station No. 5, two rather small, living shells and a few fragments. Discovery Passage at station No. 7, two small, living shells and three single valves. Johnstone Strait at station No. 10, four medium sized, living specimens (one passing distinctly into the var. rubidus) and a few very small ones. Queen Charlotte Sound at station No. 14, one living specimen; at station No. 1 T, three small living shells; and at station No. 18, one small, liviug shell. Quatsino Sound at stations No. 19 and 20, a few living specimens of various sizes.

Limatura subauricurata; Montagu. Johnstone Strait at station No. 10, and Queen Charlotte Sound at station No. 14, a single living specimen from each of these localities. Not included in the Vanconver fauna in Dr. Carpenter's "Guide to the Diagnosis of the Vancouver and Californian Shells," on pages 122-150 of his last report on "The Mollusks of Western North America," published in 1872 by the Smithsouian Institution.

Yoldia lanceotata, J. Sowerby. Quatsino Sound at station No. 20, a few living specimens.

Yoldia (Portlandia) thracifirormis, Storer. From the same station as the last, two small but living specimens. This species also is new to the Vancouver district.

LEda Fossa? Baird. Discovery Passage at station No. 7, one single and worn valve.

LEDA Minuta, O. Fabricius. Quatsino Sound at station No. 19, two living specimens.

LEDA ACUTA, Conrad. (=L. cuneata, Sowerby.) Same locality aud station as the preceding; ten perfect specimens (most of which were living) and three single valves.

A single valve of a Leda from Houston Stewart Channel, Queen Charlotte Islands, which was referred by the writer to the Leda calata of Hinds (on p. 200 is of the Report of Progress of the Geological Survey for 1878-79) is almost certainly referable to $L$. acuta, Conrad, of which, according to Dall, L. cuneata, Sowerby, is a synonym. On the other hand, in the sixth rolume of the "American Journal of Conchology," (p. 55) Dr. J. G. Cooper suggests that Leda cuneata may be ouly a variety of $L$. calata. 
Nucula (Acila) Lyatili, Baird. Strait of Georgia at station No 9, Johnstone Strait at stations Nos. 9 and 10, and Queen Charlotte and Quatsino Sounds at stations Nos. $12,14,17$ and 20. Taken more or less plentifully and living at each of these localities, in from ten to thirty fathoms.

-NuCUla tenuis (Montagu), var. Lucida, Gould. Johnstone Strait at station No. 9, several living specimens. Quatsino Sound at station No.20, abundant, living but small.

/ Pectunculus subobsoletus. (=Axinca subobsoleta, Carpenter.) Discovery Passage at station No. 7, two living specimens. Queen Charlotte Sound at station No. 14, three living shells, and at station No. 15, ten living specimens. North or north-west coast of Vancouver Island, between Nahwitti Bar and Quatsino Sound, at low water, one living shell.

Crenelua decussata, Montagu. Strait of Georgia at station No. 5, two living examples of an unusually large form of the species. Queen Charlotte Sound at station No. 12, three living specimens, of the same size; and station No. 14, four specimens of the usual size and one (living) which measures, length, twelve mm., height, eleven mm., and maximum thickness, seven $\mathrm{mm}$ and a half.

Modiolaria Levigata, Gray. Port Neville, on the mainland of British Columbia, near Johnstone Strait, at low water, one living specimen associated with Saxicava rugosa.

Modiolaria nigra, Gray. Strait of Georgia at station No. 5, Discovery Passage at station No. 7, and Queen Charlotte Sound, at stations Nos. 14 and 16,-a few immature living specimens at each of these localities.

Modiola modiolus, $L$. Johnstone Strait at station No. 10, six half-grown, living shells, with a simply bearded epidermis. Queen Charlotte Sound at stations Nos. 11, 12, 14, 16 and 18,-a few living, but for the most part, very young specimens at each. The species usually lives in the crevices of rocks, or between or on stones.

- Mrtilus edulis, L. A few specimens of the fry of this very common and ubiquitous species occur in dredgings in the Strait of Georgia, at station No. 5.

Mytilus Californianus, Conrad. Low water at Galiano Island, in the Strait of Georgia, and dredged at station No. 11, in Qneen Charlotte Sound.

Keluia Laperousei, Deshayes. Low tide, entrance to Malaspina Inlet; one fine and adult living specimen, which measures twenty-five mm. (or just one inch) in length by trventy $\mathrm{mm}$. in height, and a few smaller ones.

Kellia Laperousei, var. Chironil, Carpenler. Strait of Georgia, at low water, one living shell; and Johnstone Strait, also at low water, seven living specimens.

Diplodonta orbella, Gould. Entrance to Malaspina Inlet at low water, three adult living specimens; also north or north-west coast of Vancouver Island, between Nahwitti Bar and Quatsino Sound, at low water, one adult and living shell.

Chyptodon flexuosus, $L$. Strait of Georgia at station No. 2, four large and perfect specimens; and Quatsino Sound at station No. 20, two equally perfect specimens. 
CRy ptodon sericatus, Carpenter. (Not "serricatus.") Quatsino Sound at station No. 20, several small but living specimens. In a letter to the writer, Mr. Dall says "the specific name of this shell is misspelled in Dr. Carpenter's last report, but the mistake was corrected by him in MS." / Cequetie

IJUCINA Filosa, Stimpson. Quatsino Sound at station No. 19, one small but living shell; and at station No. 20, a large and perfectly fresh single valye.

Lucina tenuiscuipta, Carpenter. Strait of Georgia at station No. 2, one living specimen ; and Quatsino Sound at station No. 19, abundant, living.

Venericirdia 13OREalis, Conrad. Living, but usnally of small size, at the following localities:-Strait of Georgia at station No. 5, Johnstone Strait at station No. 10, Queen Charlotte Sound at statious Nos. 12, 14, 15, 17 and 18; and Qnatsino Somnd at station No. 19. A few dead ralves of this shell were dredged at station No. 7, in Discovery Passage.

, Astante Undata? Gould, var. Strait of Georgia at station No. 5, two living and fullgrowu specimens; Discorery Passage at station No. 7, two living specimens and several single valves, and Johnstone Strait at station No. 10, one living and unusually large specimen.

The shells from station No. 5 can scarcely be separated from examples of a variety of $A$. undata dredged by the writer, in 1873 , between Picton Island and Cape Bear, P.E.L; while those from stations No. 7 and 10 are more transversely elongated and more like $A$. elliplica in shape, but their ribs are fewer (some fourteen or fifteen in number) and more prominent, and shew little if any tendency to become obsolete near the ventral margin. A single dead and immature valve of an Astarte, dredged by Dr. G. M. Dawson off Metlakatla in 1878, and identified by the writer, with doubt, as possibly the A. semisulcata of Leach, in the Report of Progress of the Geological Survey of $1878-79$ (p. 197 13) is certainly identical with the shells here provisionally referred to $A$. undata.

Astarte Esquimalit, Baird. Strait of Georgia at station No. 5, two living specimens; Discovery Passage at station No. 7, abundant, alive; Johnstone Strait at station No. 10, two living specimens; and Queen Charlotte Sound at station No. 12, four living shells, and at station No. 14, abundant and alive. In the specimens from these localities the irregularity of the concentric ribs is very slight and searcely appreciable without the aid of a lens.

Cardium blandum, Gould. Strait of Georgia at station No. 5, Discovery Passage at station No. 7, Johnstone Strait at station No. 10, and Queen Charlotte Sound at stations Nos. 12, 13, 16 and 17. A few living specimens of all sizes from each of these localities.

- Cardium Nutratii, Conrad. Common at or near low water mark throughout the district.

SAxidonus squalidus, Deshayes. Abundant at low tide round the whole coast. A few small specimens of the present species were dredged in Discorery Passage at station No. 7, and in Queen Charlotte Sound at stations Nos. 12 and 16. 
$\checkmark$ TAPES staminea, Conrad. Common almost everywhere on mud flats at low water. This and the two preceding species are eaten by the Indians, who call this the "small round clam."

$\checkmark$ Venus Kennerlyi, Reeve. Discovery Passage at station No. 7, one full-grown living specimen and a very small one; also in Queen Charlotte Sound at station No. 12, one very small living shell.

PsePhis LoRdr, Baird. Living, and more or less abundant, in the Strait of Georgia at station No. 5; in Discovery Passage, at station No. 7; in Johnstone Strait at stations Nos. 9 and 10; and in Queen Charlotte Sound at stations Nos. 12, 13, 14 and 17.

Clementia subdiaphana, Carpenter. Quatsino Sound at station No. 19, three large, dead, single valves.

Temuina Bodegensis, Hinds. North and north-west coast of Vancouver Island, between Nahwitti Bar and Quatsino Inlet, at low water, six living specimens.

Mara Salmonea, Carpenter. Low water at the entrance to Quatsino Sound, and Queen Charlotte Sound at station No. 16,- - one living specimen at each of these localities. By inadvertence, the name of this species was printed $M$. variegata in the list of shells from the Queen Charlotte Islands already referred to in this paper.

ANGulus Variegatus, Carpenter. Quatsino Sound at station No. 19, a fully grown living specimen.

Anavuus Modestus; Carpenter. Strait of Georgia at station No. 2, five living specimens. Probably only a pale local variety of the species last mentioned.

,Macoma obtusa, Carpenter. (Sp.) Discovery Passage at station No. 7, one adult and perfect shell; Queen Charlotte Sound at stations Nos. 15 and 16, one specimen from each, and Quatsino Sound at station No. 19, two living specimens.

Macoma CarlotTensis, Whiteaves. Johnstone Strait at station No. 9, abundant, alive; Quatsino Sound at station No. 20, seven adult living specimens.

Macoma Calcarea, Chemnitz. (=M. sabulosa, Spengler.) Quatsino Sound at stations Nos. 19 and 20 , one perfect, living specimen from each.

, Macoma Inconspicua, Broderip and Sowerby. Queen Charlotte Sound at stations Nos. 16 and 17, three living specimens at each. A single shell also, which appears to be an unusually large form of this species, was dredged at station No. 17.

Macoma nasuta, Conrad. Abundant at low water in Johnstone Strait. One small, living specimen also was dredged in Discovery Passage at station No. 7.

Lyonsia (EnTodesma) saxicola, Baird. Abundant, of large size and living, at low water, in crevices of rock among kelp and other seaweed, at Port Neville, on the mainland of British Columbia, near the east end of Johnstone Strait. Low tide at Beaver Harbour, Vancouver Island, one living specimen. Queen Charlotte Sound at station No, 11, one living adult shell. 
Lyonsia Calrfornica, Conrad. Strait of Georgia at station No. 2, one living shell; and station No. 5, abundant and alive. Discovery Passage at station No. 7, several; and at station No. 8, one, alive. Queen Charlotte Sound, a few living specimens at stations Nos. 12, 14 and 16. As is usual in this genus, the shell, when freshly taken, is often nearly covered with a fine, sandy envelopment.

Tirracia CurTA, Conrad. Quatsino Sound at station No. 19, a large left ralve, which measures a little orer two iuches in length by one inch and five-eighths in height.

Pandora (Kennerlia) arandis, Dali. Discovery Passage at station No. 7, two nearly adult living shells and one adult and perfect but dead specimen. Johnstone Strait at station No. 10, one adult, living shell.

Pandora (Kennemlia) filosa, Carpenter. Strait of Georgia at station No. 5, three living specimens-one adnlt and two small. Discovery Passage at station No. 8, three young and living specimens and one fnll grown but dead shell. Quatsino Sound at station No. 19, six adult, living specimens; and at station No. 20, one living. specimen.

Nefera PECTinata, Carpenter. One or two living specimens from each of the following localities:-Strait of Georgia at statiou No. 5, Discovery Passage at station No. 8, Johnstone Strait at station No. 10, Queen Charlotte Sound at station No. 17, and Quatsino Sound at station No. 19. The largest specimen, which measures twenty one $\mathrm{mm}$. in length and thirteen $\mathrm{mm}$. in height, is from the locality last mentioned.

Schizotharus Nutrali, Conrad. Commoin at low tide at many places along the coast and used for food. The only localities from which specimens were brought are Galiano Island in the Strait of Georgia, and Fort Rupert, Beaver Harbour, on the north coast of Vanconver Island.

Mya truncata, L. A few young specimens of this species were dredged in Discovery Passage at station No. 8, in Johnstone Strait at station No. 10, in Queen Charlotte Sound at station No. 12, and in Quatsino Sound at station No. 20.

Saxicava pitoladis, L. (=S. rugosa, Lamarck.) A few specimens of this common littoral species were collected at low water at the entrance to Malaspina Inlet, at Port Neville, B. C., and Quatsino Sound. A living but immature specimen, also, was dredged at station No. 20 in Quatsino Sound.

\section{Gasteropopa.}

Tornatina Eximia, Baird. Strait of Georgia at station No. 5, Discovery Passage at stations Nos. 7 and 8, Queen Charlotte Sound at station No. 17, and Quatsino Sound at station No. 20. A few living specimens from each of these localities.

CylichNa Alis, Brown. Associated with the above at stations Nos. 5 and 20, one specimen at the first locality and five at the last.

, Melibe (Chiorhas) teonina, Gould. On seaweed in Cnllen Harbour, sereral. 
Dendronotus PuRpureus? Bergh. Elk Harbour, one large and two small living specimens.

(Siphonaria Thersites, Carpenter. Living and apparently not uncommon, at low tide, in Johnstone Strait, on the east side of Queen Charlotte Sound; on the north and north-west coast of Vanconver Island, from Nahwitti Bar to Quatsino Sound, and in Quatsino Sound.

Cadulus aberrans. N. Sp.

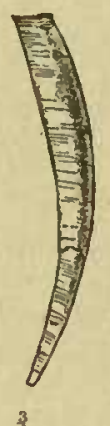

Fig. 2.-Cadulus aberrans. Side view of an average specimen, enlarged three diameters.

Shell slender, moderately but distinctly curved, large and much elongated for the genus, increasing very slowly but regularly in diameter, not distinctly (if at all) swollen in advance of the middle, and very slightly and searcely perceptibly constricted immediately behind the aperture. Test extremely thin, surface polished, very glossy and shining, smooth to the naked eye, but under a lens it is seen to be marked with minute and transverse but somewhat oblique lines of growth.

Length of an average, full-sized example, $13.5 \mathrm{~mm}$; greatest breadth of the same near the anterior end, $1.3 \mathrm{~mm}$.

Very abundant in Quatsino Sound at station No. 20.

This little shell, which is nevertheless of large size for the genus, looks not unlike an immature Dentalium, and, at first sight, specimens of it might be easily mistaken for half-grown examples of $D$. pretiosum, Nuttall, which the Indians say occurs at the same locality. It may, however, be distinguished from any Dentalium by its thin test and highly polished outer surface, though the swelling of the shell in advance of the middle and the constriction behind the aperture, which are usually marked characters in the genus Cadulus, are reduced to a minimum in this species, and in most specimens are quite imperceptible.

The writer has been informed by Mr. Dall that there are specimeus of this shell in the museum of the Smithsonian Institution at Washington, which were collected by Dr. J. G. Cooper at Catalina Island, California.

Mopaiıa Ciliata, Soverby. (Sp.) More or less abmudant, living, at low tide, in Discovery Passage, Johnstone Strait, the Goletas Channel, and Quatsino Sound. One living specimen was dredged in Queen Charlotte Sound at station No. 13.

Mopaina lignosa, Gould. Living, at low tide, on the north side of the Strait of Georgia, in the Goletas Channel; and in Queen Charlotte and Quatsino Sonnds. 
Mopalia Wossnessenskyi, Middendorf. Associated with the two preceding species, but apparently very much rarer than either.

Placiphorelia imporcata, Carpenter. (Sp.) Johnstone Strait at station No. 10, one small, living specimen, with the girdle partly overgrown by a hydroid.

Cryptochiton Stelleri, Middendorf. Discovery Passage, between Vancouver and Cortez Islands, in about one fathom of water, one living specimen. Low tide, Johnstone Strait, two living specimens; and on Thurlow Island, east end of Johnstone Strait, four living shells. Low tide, Beaver Harbour, Vancouver Island, one living specimen. One living specimen, also, was dredged in Queen Charlotte Sound at station No. 15.

Dr. Dawson states that this species is generally distributed on rocky ground at and below low tide mark, but that it is nowhere very abundant. This and the next-named species are cooked and eaten by Indians.

Katherina tunicata, Sowerby. On rocks at low water all over the coast, and in some places very abundant.

Leptochiton cancellatus, Sowerby. Queen Charlotte Sound at station No. 12, eleven small but living specimens, four of which have been identified with this species by Mr. W. H. Dall. Three specimens of a small, white Chiton, from station No. 14, appear also to belong to this species.

Leptochiton PUNCTATUs. N. Sp.

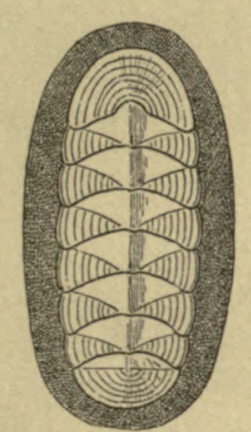

$\stackrel{3}{1}$

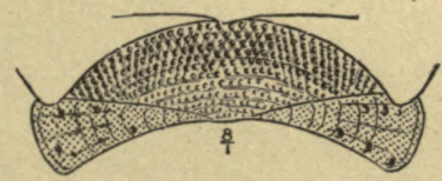

Figs. 3 and 4.-Leptochiton punctatus. The figure on the left hand side represents the type specimen enlarged three diameters, and that on the right one of the central valves, enlarged eight diameters to shew the sculpture.

Shell small, elongated, rather strongly elevated, back distinctly angulated; colour, pale cream or nearly white, but with a few small patches of reddish-brown on the girdle, and a narrow and non-continuous series of variously interrupted and broken up yellowish-brown spots upon the median line of all the valves but the anterior one. Girdle squamose, the scales closely imbricating, much broader than high, and distinctly striated when viewed under an achromatic microscope with a half-inch objective. Mucro central and tolerably distinct where not worn off; anterior valve marked with faint but rather numerous radiating striæ and 
concentric lines of growth. Central areas of all the valves but the anterior one regularly pitted, as viewed by an ordinary simple lens of moderate power, the pitting being most distinct near the suture. These pits are the interstices between longitudinal, lightly curved and convergent raised lines, and the curved raised lines of growth. Lateral areas of the valves (exclusive of the anterior one) not so distinctly pitted, but more or less marked with faint radiating strix, especially those of the anterior portion of the shell; those of the third to the seventh, both inclusive, each bearing from four to six distant, isolated, prominent and rounded tubercles on each side, three being usually placed on each of the lines which separate the lateral from the central areas.

Leugth of the only specimen collected, about fourteen millimetres; maximum breadth of the same, six and a half.

Discovery Passage at station No. 7, one living, specimen.

An interesting and beautiful little species, apparently well characterized by the peculiarly punctate surface of the central area of the valves.

Tonicelda tineata, Wood. (Sp.) Frequent, living, at low water, on the north shore of the Strait of Georgia, in Malaspina Inlet, Discovery Passage, Race Passage in Johnstone Strait, Queen Charlotte Sound, and on the north and north-west coast of Vancouver Island, from Nahwitti Bar to Quatsino Sound. Taken abundantly from the stomach of a harlequin duck (Histrionicus torquatus) shot at Mittlenatch Island, in the Strait of Georgia. Dredged also in Queen Charlotte Sound at station No. 12.

Ischnochiton interstinctus, Gould. (Sp.) Low tide in Race Passage Johustone Strait, and in Queen Charlotte Sound, but apparently not common. More abundant in Discovery Passage at station No. 7, in Johnstone Strait at station No. 10, in Queen Charlotte Sound at stations Nos. 12, 14, 15 and 16, and in Quatsino Sound at station No. 20.

IsChNORADSIA TRIFIDA, Carpenter. (Sp.) Queen Charlotte Sound, one large, living specimen.

Lepidopleurus Mertensis, Middendarf. (Sp.) Discovery Passage at station No. 7, two living specimens; and Queen Charlotte Sound at station No. 15, one living example.

Acmaa (Comliselia) patina, Eschscholtz. Abundant, living at low tide in Johnstone Strait.

' ACM a (Colliselia) Petita, Esclescholtz. Common and alive at low tide at the north end of Texada Island, Strait of Georgia; in Discovery Passage, between Seymour Narrows and EIk Harbour; in Johnstone Strait; on the enst side of Queen Charlotte Sound; and along the north and north-west coast of Vanconver Island, from Nahwitti Bar to Quatsino Sonnd. Numerous but dead specimens were dredged in Discovery Passage at station No. 7.

Acmata (Colitisella) Persona, Eschscholtz. Low tide in Discovery Passage, betwcen Seymour Narrows and Elk Harbour, four adult, living specimens. 
ACMra MTRA, Eschscholtz. Low tide at Malaspina Inlet in the Strait of Georgia, and Queen Charlotte and Quatsino Sounds. Dredged also in Queen Charlotte Sound at stations Nos. 12, 15 and 18, and at the entrance to Quatsino Inlet at station No. 19. Moderately abundant near low water mark almost everywhere.

Acman INstabilis, Gould. Low tide on the north and north-west cuast of Vancouver Island, between Nahwitti Bar and Quatsino Sound; three adult, but dead shells.

Chrptominanchia concentrica, Middendorf. (=Lepela cacoides, Carpenter.) Queen Charlotte Sound at station No. 17, one living specimen; and Quatsino Sound at station No. 20, several.

Glypits Aspera, Eschschollz. Common, living at low tide in Malaspina Inlet, Strait of Georgia; in Johnstone and Broughton Straits; in the Goletas Channel, and on the west coast of Vancouver Island, north of Quatsino Sound.

Puncturelia cuculalata, Gould. Low water at Race Passage, Johnstone Strait, one large, living specimen. Dredged also alive, but sparingly, in Discorery Passage at station No. 7, in Queen Charlotte Sound at stations Nos. 12 and 17, and in Quatsino Sound at station No. 20.

Puncturelia galeata, Gould. Dredged living, but in very small numbers, in Discovery Passage at station No. 7, in Johnstone Strait at station No. 10, in Queen Charlotte Sound at stations Nos. 12, 15 and 18, and in Quatsino Sound at station No. 20. Specimens sometimes occur which seem to be intermediate in their sculpture between this and the preceding-species.

Hailotis Kamtsciratkana, Jonas. Living at a little below low tide at Port Neville, on the mainland of British Columbia, north of Johnstone Strait; at Beaver Harbour, .on the north-east coast of Vancouver Island; in the Goletas Channel; and at the eutrance to Quatsino Iulet. Dr. Dawson says that this species is most abundant in cxposed situations on the northern and outer coast of Vancouver Island, but that it is rarely met with in the Strait of Georgia or other land-sheltered waters.

The animal, or foot of the animal, is eateu by the Indians, and dried for sale to the Chinese, while the nacreous interior of its shell is largely used by the Indians for inlaying and other ornamental or decorative purposes.

PAChy Poma gibibrosum, Chemnitz. Ou rocks and kelp at a little below low-water mark in Quatsino Sound; abundant at some localities.

The thick, calcareous operculum of this shell is used for ornamental inlaying, in wooden ware, by the Indians of the coast.

Leptotuy RA SANGUiNeA, L. (Sp.) Living, at low tide, in Johnstone and Broughton Straits, in the Groletas Chamel, and on the east side of Queen Charlotte Sound. Dredged, also, in Queen Charlotte Sound at station No 15, and in Quatsino Sound at station No. 20.

Mr. Tryon appears to be mistaken in supposing that the Californian shells which Dr. Carpenter referred to this species, have a "corneons" operculum and 
are different from the Turbo sanguineus of Limmus. ${ }^{1}$ In a letter to the writer, Mr. Dall says:- "The west coast shell is the sanguineu, L.; is not the type of Collonia, Gray, which is African and umbilicated, and has a calcareous operculum. It inhabits Japan, California, and the, Agean Sea." The specimens collected by Dr. Dawson certainly have a calcareous opereulum.

Chlorostoma funebralie, A. Adams. Collected abundantly, living, at or a little below low tide level on the north and north-west coast of Vancouver Island, between Nahwitti Bar and Quatsino Sound. Apparently confined to the north and west coast of the island.

Calinostoma costatum, Marlym. Low. tide in Johnstone and Broughton Straits, in the Goletas Channel, and on the east side of Queen Charlotte Sound,-common and living. Dredged also, abumdantly and alive, in Queen Charlotte Sound at station No. 15.

Calisostoma annulatum, Martyn. Johnstone Strait at station No. 10, one small, living specimen. A much scarcer species than the preceding one on the coasts of Vancourer and the Queen Charlotte Islands.

Gibbula (Phorcus) puluigo, Marlyn. Abundant at and a little below low water mark, in Johnstone and Broughtom Straits, in the Goletas Channel, on the east side of Queen Charlotte Sound, and on the northern and western coasts of Vancouver Island; often on fronds and stems of Macrocystis.

The specimens from Carpenter Bay, which were referred by the writer to the Chlorostoma brunneum of Philippi, in a list of shells from the Queen Charlotte Islands, published in the Report of Progress of the Geological Survey of Caula for 1878-79 (p. $201 \mathrm{~B}$ ), are forms of this species. The true Chlorostoma brunneum has not yet been found north of California.

, Solarielta peramabilis, Carpenter. Six fine living specimens of this rare shell were dredged in Queen Charlotte Sound at station No. 17. The species had not preriously been recorded as occurring north of California. Mr. W. H. Dall, who has examined three of the specimens collected by Dr. Dawsou, says that they are "ruder and larger than those from the Santa Barbara Chanuel," and that the former "might perhaps be regarded as a local variety of the species." Dr. Paul Fischer ("Manuel de Conchyliologie," Paris, p. 826) says that Macharoplax of Friele (1877) is syuonymons with Solariella of Searles Wood (1842).

/Margarita cidaris, $A$. Adams. Johnstone Strait at station No. 10, two very young but living shells. Queen Charlotte Sound at station No. 17, a fine series of eighteen living specimens of all ages, several being adult, and the largest measuring forty six millimetres in height (or length) by about thirty-two in maximum breadth. Entrance to Quatsino Inlet at station No. 19, two half-grown and dead shells.

The only previously known specimen of "this rery remarkable and unique shell," as Dr. P. P. Carpenter calls it, was foumd at Neeah Bay, Washington Territory, by Mr. J. G. Swall. 
In one of the specimens collected by Dr. Dawson the columella has a greenish iridescence not unlike that of some varieties of labradorite.

Marcarita pupilua, Goull. Collected sparingly, alive, at low water mark in Benver Harbour (on the north-east coast of Vancouver Island), in the Goletas Channel, on the east side of Qucen Charlotte Sound, and at the entrance to Quatsino Sound. Dredged also, in small numbers but living, in the Strait of Georgia at statious Nos. 2, 5 and 6, in Discovery Bay at station No. 7, in Johnstone Strait at station No. 10, in Queen Charlutte Sound at stations Nos. 12, 14, 16, 17 and 18, and in Quatsino Sound, at station No. 20.

Margarita lirulata, Carpenter Discovery Passage at station No. 17, one very small living specimen; Queen Charlotte Sonnd, at station No. 12, about twenty adult liring specimens; and Quatsino Sound at station No. 20, one living and fullgrown shell.

In the seventh volume of the "American Journal of Conchology," (pp. 128, 129) Mr. Dall expresses the opinion that Gibbula optabilis, Cpr., G. parcipicla, Cpr., G. funiculala, Cpr., G. succincla, Cpr., and perhaps G. lacunata, Cpr., as well as Margarila tenuisculpta, Cpr., are all forms of the present "protean species."

Margarita inelicina, Fabricius. Low tide in Johnstone Strait, three immature, living specimens. Dredged also in Queen Charlotte Sound at stations Nos. 12 and 16, oue living, adult shell at each.

Crepidula dorsata (Broderip), var. lingulatia, Gould. (=C. bilobala, Reeve.) Low tide at the entrance to Malaspina Inlet, in the Strait of Georgia, and in Quatsino Sound; three or four living specimens at each locality. Dredged also very sparingly, but alive, in the Strait of Georgia at station No. 2, and in Johnstone Strait at station No. 10.

Crepidula adunca, Sowerby. Entrance to Quatsino Sound at low water, and on the west coast of Vancouver Island, north of Quatsino Sound, also at low water,-a single specimen at each of these localities.

Crepidula Navicelloides, Nullall. Dredged in very small numbers, but alive, in Queen Charlotte Sound at stations Nos. 12, 14 and 16. Mr. Tryou thinks that this shell is only a local variety of $C$. Lessoni, Broderip.

Gaierus fastigiatus, Gould. Not uncommon and living, in Discovery Passage at station No. 7, in Johnstone Strait at station No, 10, and in Queen Charlotte Sound at stations Nos. 12, 14 and 16. The Galerus from the Queen Charlotte Islands, which was named $G$. conlorlus, Gould, $b_{z}$ the writer, in the paper already referred to, is almost certainly G. fastigiatus, but this latter name, Mr. Tryon says, is a synonym of $G$. mamillaris, Broderip.

Brvonia compacta, Carpenter. Discovery Passage at station No. 7, a living specimen on Trophon lenuisculplus, Carpenter; and in Quatsino Sound at station No. 19, one specinen, also living, attached to the under valve of a typical example of Pecten hastalus. 
Mesalia Reticulata, Mighels. (=Turritella lactea, Moller, and Mesalia lacteola, Carpenter.) Dredged rather abundantly, living, in the Strait of Georgia at station No. 5, in Discovery Passage at station No. 8, in Johnstone Strait at station No. 10, in Queen Charlotte Sound at stations Nos. 12, 13, 14 and 17, and in Quatsino Sound at station No. 20.

Bitrium filosum, Gould. Common, living, at low tide, in Malaspina Inlet, Strait of Georgia; in Discovery Passage, between Seymour Narrows and Elk Harbour; in Johnstome Strait, the Goletas Channel, and Queen Charlotte and Quatsino Sounds.

Bintium munitum. (=Cerithiopsis munila, Carpenter.) Queen Charlotte Sound at station No. 12, ten fine and mostly living specimens. The writer is indebted to Mr. W. H. Dall for the suggestion that this shell is probably a Bittium rather than a Cerithiopsis, and that the Cerithiopsis columna of Dr. Carpenter is only an abnormal form of it.

/ Litrorina Sitchana, Philippi. A common littoral species throughout the district. A few specimens of it were dredged in Discovery Passage, at station No. 7. The late Dr. Jeffreys regarded this shell as only a local variety of the European $L$. rudis.

/ LitTorina scuturata, Gould. With the preceding species, but apparently not quite so common.

LACUNa solidula, Loven. (=L. carinata, Gonld.) A few living specimens were taken at or near low water in Alert Bay, B. C., and it was dredged living, but in very small numbers, in Discovery Passage at station No. 8, and in Queen Charlotte Sound at stations Nos. 12 and 15. Dr. Jeffreys was of the opinion that this shell is a variety of $L$. divaricata, Fabricius (=L. vincta, Montagu), of northern Europe.

Barleeia subtenuis, Carpenter. Queen Charlotte Sound at station No. 12, one living specimen.

, Surcula PERversa, Gabb. Queen Charlotte Sound at station No. 16, one large, living specimen, an inch and three-quarters in length, and another small but living shell ; and station No. 17, an immature but living specimen.

This large and remarkable species, which is invariably sinistral, was previously dredged alive by Mr. James Richardson in from thirty to seventy fathoms in the Strait of Georgia. In the young state the test is nearly smooth and covered by a very pale, greenish-grey epidermis, and the body whorl is encircled by two spiral bands of a faint reddish-brown tint, one next to the suture and the other a little below the middle.

BELA FIDICULA, Gould. Johnstone Strait at station No. 10, four specimens; Queen Charlotte Sound at stations Nos. 14 and 16,-one living specimen at the first, and two full-grown, living shells at the second.

Bela tabulata. (=Mangelia tabulata, Carpenter.) Queen Charlotte Sound at station No. 16, two specimens. Perhaps only a variety of the last named species.

$\checkmark$ Bela violacea, Mighels, var. (Teste Dall.) Queen Charlotte Sound at statiou No. 14, one living specimen. 
Turbonilla Vancouverensis. ( Chemnitzin Vanconverensis, Baird.) Discovery Passage at station No. $\boldsymbol{\uparrow}$, one liring shell; Johnstone Strait at station No. 10, one living shell; Queen Charlotte Sound at station No. 13, eight living examples of a whiteshelled variety of this species.

Odostomia Sitkensis, Dall. Strait of Georgia at station No. 2, one living and full-grown specimell.

Eulima polita, $L$. Living and frequent in the Strait of Georgia at stations Nos. 5 and 6, in Discovery Passage at stations No. 7 and 8, in Johnstone Strait at station No. 10, in Queen Charlotte Sound at stations Nos. 14, 15 and 17, and in Quatsino Sound at station No. 20.

About fifty liring specimens of this shell were dredged by Dr. Dawson, and the only observable difference between them and authentic English examples of E. polita is one of size, the former attaining frequently to a length of thirteen millimetres, while the latter are sometimes as much as sixteen $\mathrm{mm}$. long. Smaller specimens of the same shell were dredged by Mr. Richardson in the Strait of Georgia in 1875, and these were referred by the writer to the E. micans of Carpenter, in "Canadian Naturalist," Vol. VIII, N. S.; but Dr. Carpenter himself regarded E. micans as "perhaps a smaller rariety of the European E. polita."

Eulma incurva, Renieri (=E. distorta, auct.) With the above, but not nearly so common, at stations Nos. 6, 10 and 14. Two living specimens were also taken at low tide in Discorery Passage, between Seymonr Narrows and Elk Harbour, and one at low tide in the Goletas Chanuel.

Scalaria Indianorum, Carpenter. One fine, living adult specimen of this species, measuring nearly an, inch and a half in length, was dredged in Discovery Passage at station No. 7 .

Cancelalaria circumcincta, Dall. Johnstoue Strait at station No, 10, one living and adult specimen; Queen Charlotte Sound at station No. 12, a series of about twenty living specimens, and at station No. 13, one full-grown living shell.

Admete viridula, Fabricius. Queen Charlotte Sound at stations Nos. 12 (three living specimens), 17 (two living specimens), and 18 (one living specimen). Most of these belong to the short-spired rariety of the species, to which Verkruzen has given the name undatocostata.

Trichotropis cancellata, Hinds. Dredged more or less abundantly, alive, in the Strait of Georgia at station No. 5, in Discovery Passage at station No. 7, in Johnstone Strait at station No. 10, and in Queen Charlotte Sound at stations Nos. 12, 13, 15, 16, 17 and 18. Taken living also, in some numbers, at low water in Johnstone Strait and the Goletas Channel.

Velutina lexigata, $L$. Discovery Passage at station No. 8, one living specimen.

Natica Clausa, Broderip and Sowerby. Taken sparingly, but alive and in some cases of considerable size, at low water, on the north shore of the Strait of Georgia; in 
Johnstone Strait; at Beaver Harbour, Vancouver Island; on the east side of Queen Charlotte Sound, and on the north and north-west coast of Vancouver Island between Nahwitti Bar and Quatsino Sound. Dredged also, alive, but in small numbers, in the Strait of Georgia at station No. 5, in Discovery Bay at station No. 7, and in Queen Charlotte Sound at stations Nos. 12 and 17.

Lunatia Lewisir, Gld. Low tide, entrance to Malaspina Inlet, one specimen.

Lunatia Pallida? Broderip and Sowerby. Queen Charlotte Sound at station No. 17, two dead and imperfect shells.

Triton (Priene) Oregonensis, Redfield. Low tide in Johnstone and Broughton Straits, in the Goletas Channel, and on the east side of Queen Charlotte Sound, but apparently not very common. Dredged, living and adult, but in very small numbers, in Johnstone Strait at station No. 10, and in Queen Charlotte Sound at stations Nos. 11 and 12. This shell is possibly ouly a local variety of the Triton cancellatus of Lamarck, from South America.

Marainelia (Volutelia) Pyriformis, Carpenter. Low tide in the Goletas Channel; dredged also in Queen Charlotte Sound at station No. 12, and in Quatsino Sound at station No. 20. One adult, living shell of this diminutive species at each of these stations.

Otivelua BiPlicata, Sowerby. Abundant, living, on the west or outer coast of Vaucouver Island.

Olivelua Bestica, Carpenter. Strait of Georgia at stations Nos. 2 (frequent) and 5 (very abundant), also in Discovery Passage at station No. 7, and in Queen Charlotte Sound at station No. 16. Living, and apparently not uncommon, at each.

Chrysodomus Liratus, Martyn. Queen Charlotte Sound, at station No. 12, two living but very young specimens, with the mammillated apex beautifully preserved; at station No. 16, one half-grown and dead specimen; and at station No. 17, two fine adult specimens (one living), with a short spire to the shell and an unusually inflated or globose body whorl.

Chrysodomus dirus, Reeve. (Sp.) Abundant, living, at low water at the entrance to Malaspina Inlet and on the north shore of the Strait of Georgia ; in Discovery Passage, between Seymour Narrows and Elk Harbour; in Johustone and Broughton Straits; in the Goletas Channel, and on the east side of Queen Charlotte Sound. Dredged, but in small numbers, in Discovery Passage, at station No.7. The generic position of this species is uncertain, as the animal has not yet been described. The shell does not look like that of a Chrysodomus or Sipho. Tryon places it in the genus Euthria, but that course is not free from objections.

SiPhon Verkruzeni, Kobelt. Queen Charlotte Sound at station No. 17, associated with Neptunea lirata and other rare species; one large, dead shell, but in excellent condition. Mr. Dall, to whom the writer is indebted for the identification of this specimen, writes that it had previously beell found in Norway and in Behring Sea and Strait, but that the present is the most southerly locality yet reported for it. 
Buccinum polare (Gray), var. Compactum, Dall. At the same station as the species last mentioned; one adult but dead shell, in good condition. This species was collected by Mr. James Richardson, at low water, near Victoria, Vancouver Island, in 1875.

NAssa (Tritia) meNDica, Gould. Strait of Georgia at station No. 5, alive and plentiful; Jolnustone Strait at station No. 10, one living specimen; Queen Charlotte Sound at station No. 12, several living shells; and Quatsino Sound at station No. 20, ten living specimens.

Astrin carinata (Hinds), var. Hindsir. (=Columbella Hindsii, Reeve.) Low tide in the Goletas Channel, one living specimen. In this species the nuclens of the operculum is said to be subcentral, or "somewhat more within the margin" than it is in that of Nitidella Gouldii.

- Nitidelat Gouldir, Carpenter. Strait of Georgia at station No. 2, two living specimens, and at station No. 5, abundant and living; Quatsino Sound at station No. 19, three living specimens.

This shell has been separated from the preceding species, both generically and specifically, mainly upon minute differences in the opercula, the nucleus of the operenlum of $N$. Gouldii being stated to be nearly marginal. Mörch, Dall and Fischer, however, assert that in the Columbellidxe the operculum is so variable that it does not afford a good character for the discrimination of genera or species, and Tryon, in his "Manual of Conchology," places $N$. Gouldii among the synonyms of Columbella carinata.

Amphissa corrugata, Reeve. Common, living, at low tide, at the entrance to Malaspina Inlet; in Race Passage and other localities in Johnstone Strait; in the Goletas Channel, and in Queen Charlotte and Quatsino Sounds. Dredged also, alive and in some numbers, in the Strait of Georgia at station No. o, and in Queen Charlotte Somnd at stations Nos. 15, 16, 17 and 18 .

Purpura crispata, Chemnitz. (=P. lactuca, Eschscholtz.) Extremely abundant and very variable in size, shape, sculpture and colour, living at or near low water mark, on the north shore of the Strait of Georgia, in Discorery Passage, in Johnstone and Broughton Straits, in the Goletas Chamnel, on the east side of Queen Charlottc Sound, and at the entrance to Quatsino Sound. Dredged also abundantly, alive, in Discovery Passage at station No. 7, and in very small numbers in Johnstone Strait at station No. 10, and in Queen Charlotte Sound at station No. 16.

Purpura lima, Mantyn. (=P. canalicutata, Duclos.) At low water throughout the district, associated with the preceding, of which Von Martens and others regard it as only a local variety. It did not, however, occur at any of the stations where the dredge was used.

Purpura saxicola, Valenciennes. Queen Charlotte Sound, at low tide, five adult, living shells of a variety in which the interior of the aperture and part of the columella is stained dark brown, while the former is margined exteriorly by a band of pale straw colour. Vou Martens and other writers regard this shell as a inere variety of P. lima, Martyn. 
Ocinebra lurida, Middendorf. Low tile in Johnstone Strait, one living, adult specimen ; Queen Charlotte Sound at station No. 13, an immature and dead shell.

Ocinebra interfossa, Carpenter. Living, at low tide, but by no mealls common, in Johnstone Strait and the Goletas Channel ; on the east and north west coast of Vancouver Island, from Nahwitti Bar to Quatsino Sound, and at the entrance to Quatsino Sound. One adult, living specimen was dredged at station No. 20.

Cerostoma foliatum, Gmelin. Fine and frequent, living, at low tide, at Twin Island and the entrance to Malaspina Inlet, in the Strait of Georgia ; in Johnstone and Bronghton Straits; in the Goletas Channel, and on the east side of Queen Charlotte Sound. Dredged also, living and adult, in Discovery Passage at station No. 7.

Trophon OrPheus, Gould. (=T. Sluarli, E. A.Smith.) Queen Charlotte Sound, at station No. 14, an immature, living shell, nearly an inch and a half long, with the varices prolonged behind into semitubular or deeply grooved, long, spiny frills, which curve lightly backward; at station No. 16, a living, adult shell, fully two inches long; and at station No. 18, a beautifully preserved living specimen, an inch and a quarter in length, with the spinose frills prolonged to an unusual length behind.

Trophon clathratus, $L$. (=T. mullicostalus, Eschscholtz.) Low water in Johnstone Strait, one adult, living specimen. A similar, but slightly larger one was dredged in Queen Charlotte Sound at station No. 12, and another at station No. 16.

Trophon TENUISCULPTis, Carpenter. (=T. subserratus, Sowerby.) Not uncommon, alive, at low tide, on the north side of the Strait of Georgia, in Seymour Narrows, and in the Goletas Channel. A few liring specimens, also, were dredged in Discovery Passage at station No. 7, in Johnstone Strait at station No. 10, in Queen Charlotte Sound at stations Nos. 12, 16, 17 and 18, and in Quatsino Sound at station No. 19.

The largest specimens collected are a little more than an inch and a half in length. When examined with an ordinary simple lens, the whole surface of the shell of this species is seen to be almost covered by deusely-crowded, minute, crenate and squamose raised lines of growth, which cross the spiral grooves and ridges and are superimposed upon the varices. The types of T. lenuisculptus are from the Pleistocene deposits at San Diego, but the shell is by no means uncommon in a living state on the coasts of Vancouver and the Queen Charlotte Islands.

\section{Cephatopoda.}

Ommastrephes sagitTatus, Lamarck. (Sp.) Three specimens of a squid, which correspond very well with Tryon's description and figures of this species in the first volume of his "Manual of Conchology," were collected at low water in Victoria Harbour, Vancouver Island.

The following is a supplementary list of fresh-water and land shells, fishes (marine), batrachians, ophidia, birds and mammals collected by Dr. Dawson and Mr. Dowling in the same district and season :- 
Fresh-Water Shells.

Margaritana margaritifera, $L$. Small streams entering Malaspina Strait, on the mainland side, four small specimens.

\section{LAND SHELLS.}

Selenites Vancouverensis. (=Helix Vancouverensis, Lea.) Harbledown and Pender Islands, in Johnstone Strait; and Malcolm Island, in Broughton Strait; a few living examples at each of these localities. Quatsino Sound, one dead and bleached shell.

Ariolimax Columbianus? Gould. Malcolm Island, Broughton Strait, three specimens in alcohol. These have not been dissected, and therefore may possibly be A. Californicus, Cooper.

Mesodon Columbianus, Lea. Taken sparingly on Harbledown and Pender Islands, with Selenites Vancouverensis.

Aglaia fidelis, Gray. North point of Texada Island, three living and six dead ; entrance to Malaspina Inlet, one alive; and False Bay, Lasqueti Island, one alive; Growler Cove, Broughton Strait, one alive and one dead.

\section{Fishes.}

Merludius Productus, Ayres. Merluccio. Off Gabriola Island, in the Strait of Georgia. In this fish the scales on the sides of the body, which have been described as very small, are really comparatively large and measure six millimetres by four. They are, however, rery easily rubbed off.

Gadus Proximus, Ayres. Pacific Tom Cod. Caught in Alert Bay, Cormorant Island, at station No. 14.

LiPARIS PULCHELLA, Ayres. Taken by the dredge at a depth of thirty fathoms in Queen Charlotte Sound.

Sebastodes mystinus, Jordan and Gilbert. Black Rock-Fish. Caught in Queen Charlotte Sound at station No. 12.

Anoploma fimbria, Pallas. Coal Fish. Taken at Broughton Strait, near Helmken Island.

Ammodytes personatus, Girard. Pacific Sand Launce. Alive near shore at Beaver Harbour, Vancouver Island.

Siphostoma Caiforniense, Storer. Big Pipe-fish. Two rather small specimens of this species were collected in the Strait of Georgia. 
Chimara Coldidei, Bennett. "Rat-fish" or "Elephant Fish" of American icthyologists, but according to Dr Dawson known locally as the "Silver Dog Fish." Queen Charlotte Sound at station No. 14, one adnlt male. A similar specimen was collected by Dr. Dawson in 1878, in deep water off the Queen Charlotte Islands.

\section{Batrachia.}

Diemyctylus torosus. (=Triton torosus, Eschscholtz, and Taricha torosa, Gray.) The Warty Salamander. Texada Island, in the Strait of Georgia, and Coal Harbour, Quatsino Sound,-one specimen at each of these localities.

\section{Ophidia.}

Eutainia Pickeringir, Baird and Girard. Pickering's Garter Snake. Oyster Bay, near Comox, one specimen two feet and tbree-quarters of an inch in length; and Georgina Point, Malaspina Inlet, one specimen not quite two feet loug.

\section{BIRDS.}

Brachyrhamphus marmoratus, Gmelin. (Sp.) Marbled Guillemot. Northern end of Vancouver Island, two specimens.

Podiceps CORNuTus (Gmelin) Latham. Horned Grebe. Two young specimens of this species were shot at Growler Cove, Johnstone Strait, and one equally young at Farewell Harbour, Queen Charlotte Sound.

Podiceps GRISEIGENA? Boddaert. Red-necked Grebe. A young grebe which may be referable to this species was shot in Broughton Strait.

Chroicocephalus Philadelphia (Ord) Lawrence. Bonaparte's Gull. False Bay, Lasqueti Island, one immature specimen.

Larus (Blasipus) Heermanni, Cassin. White-headed Gull. Malcolm Island, Broughton Strait, one not quite adult specimen.

Larus GLadcescens, Lichtenstein. Glaucous-Winged Gull. Cullen Harbour, Queen Charlotte Sound, one nearly adult specimen.

Oceanodroma furcata, Gmelin. (Sp.) Fork-tailed Petrel. Goletas Channel, north end of Vancouver Island, one specimen.

Graculus Dilophus, (Swainson) Gray. Double-crested Cormorant. Blunden Harbour, Queen Charlotte Sound; two specimens, both devoid of crests but with twelve feathers in the tail.

Oidemia perspicilitata (L.) Fleming. Surf Scoter. Comox Harbour or Port Augusta, Vancouver Island, one adult male. 
Oidemia Americana, Swainson. American Black Scoter. False Bay, Lasqueti Island, Strait of Georgia, one adult male.

Histrionicus torquatus (L.) Bonaparte. Harlequin Duck. One adult male of this species, in fine plumage, was shot on Lasqueti Island, at False Bay ; and a young male at Mittlenach Island, in the Strait of Georgia.

Mareca Americana (Gmelin) Stephens. American Widgeon. Beaver Cove, Broughton Strait, a young male.

Nettion Carolinensis (Gmelin) Kaup. Green-winged Teal. Blunden Harbour, Queen Charlotte Sound, one young male.

Ardea Herodias, L. Great Blue Heron. A young bird of this species was shot in Cullen Harbour, and a similar one in Blunden Harbour-both in Queen Charlotte Sound.

LoBIPEs HYPerboreus (L.) Cuvier. Northern Phalarope. Fresh Water Bay, Queen Charlotte Sound, one specimen.

Strepsilas melanocephalus, Vigors. Black Turnstone. Forster's Island, Queen Charlotte Souud, three specimens.

Haliaetus leucocephalus $(L$. Savigny. Bald Eagle. Johnstone Strait, one young specimen.

Colaptes Mexicanus, Swainson. Red-shafted Flicker, Comox, Vancouver Island, one specimen.

Ceryle Alcyon (L.) Boie. Belted Kingfisher. Cullen Harbour, Queen Charlotte Sound, two males and one female.

Cyanura Stelleri (Gmelin) Baird. Steller's Jay. Comox, Vancouver Island, two specimens.

\section{Mammalia.}

Sciurus Hudsonius, Pallas, var. Red Squirrel. Comox, Vancouver Island; one specimen, which differs only from the eastern form of the species in being a little smaller and not so distinctly rufous on the back.

Phoca vitulina, L. Harbour, Hair, or Leopard Seal. One specimen of the North Pacific variety of the Harbour Seal was shot in Broughton Strait. The species may be readily distinguished from all the other earless seals of both coasts of North America by the oblique implantation of its molars.

Mustela Americana, Turton. Sable. Pine Marten. Johnstone Strait, one specimen.

CANIS LUPUS, (L.) Wolf. A large red wolf was shot near Cullen Harbour; and a small grey and black variety at Knox Bay, in Johnstone Strait. 

On some marine Inverteorata...
collected by G. M. Dawson...on

the coast of British Columbig. LoGy GRARY

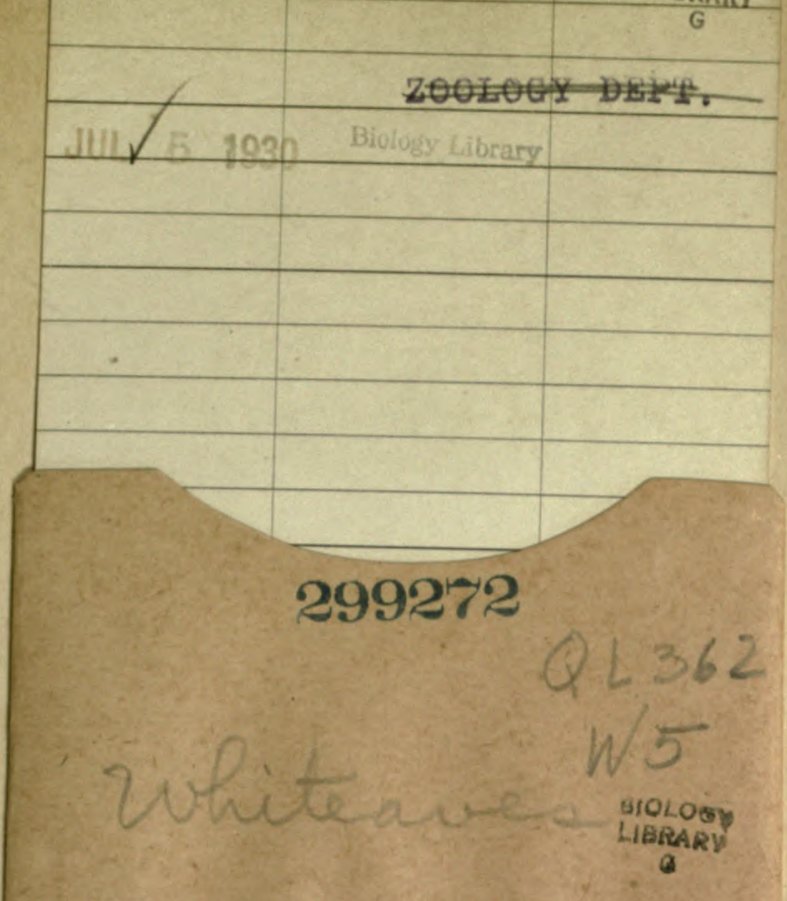

UNIVERSITY OF CALIFORNIA LIBRARY 
